
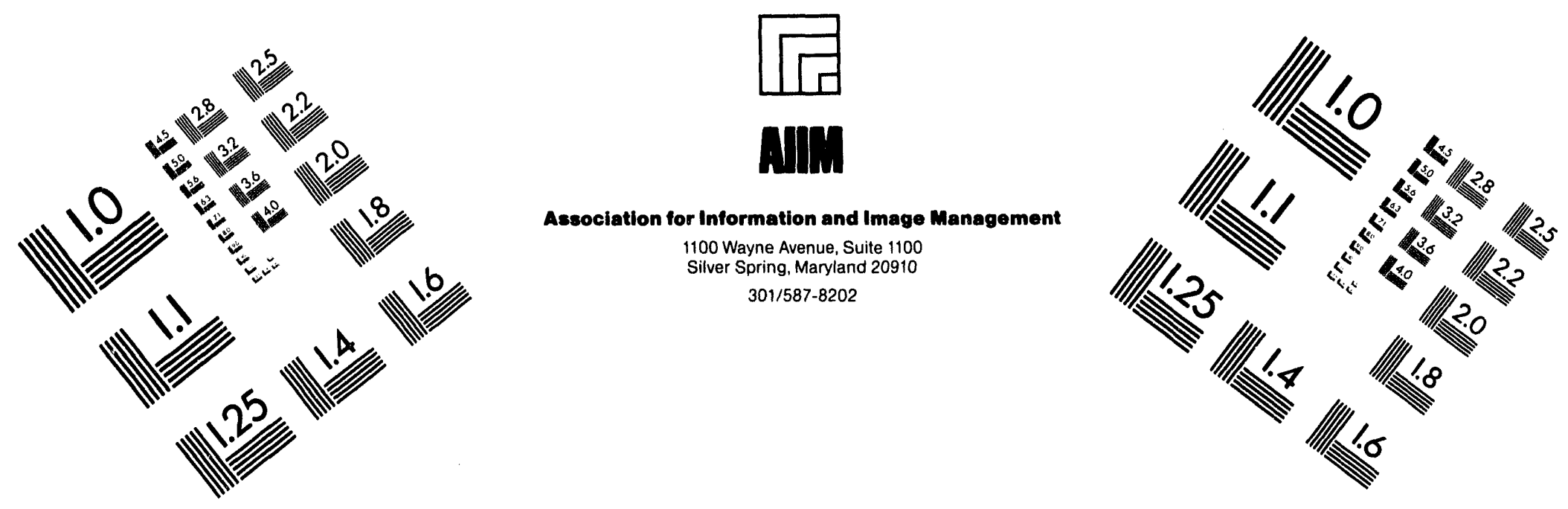

\title{
Centimeter
}

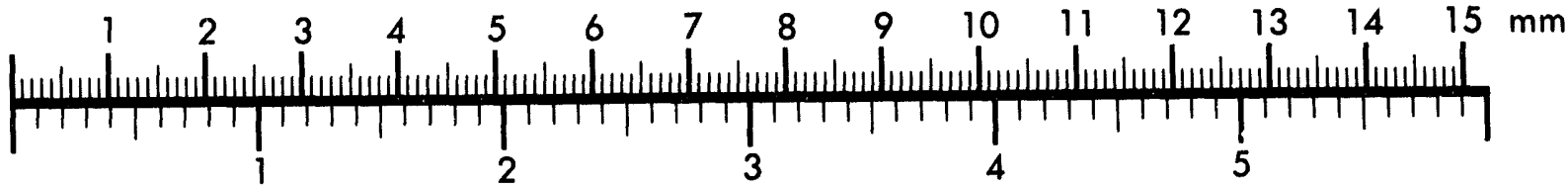

Inches
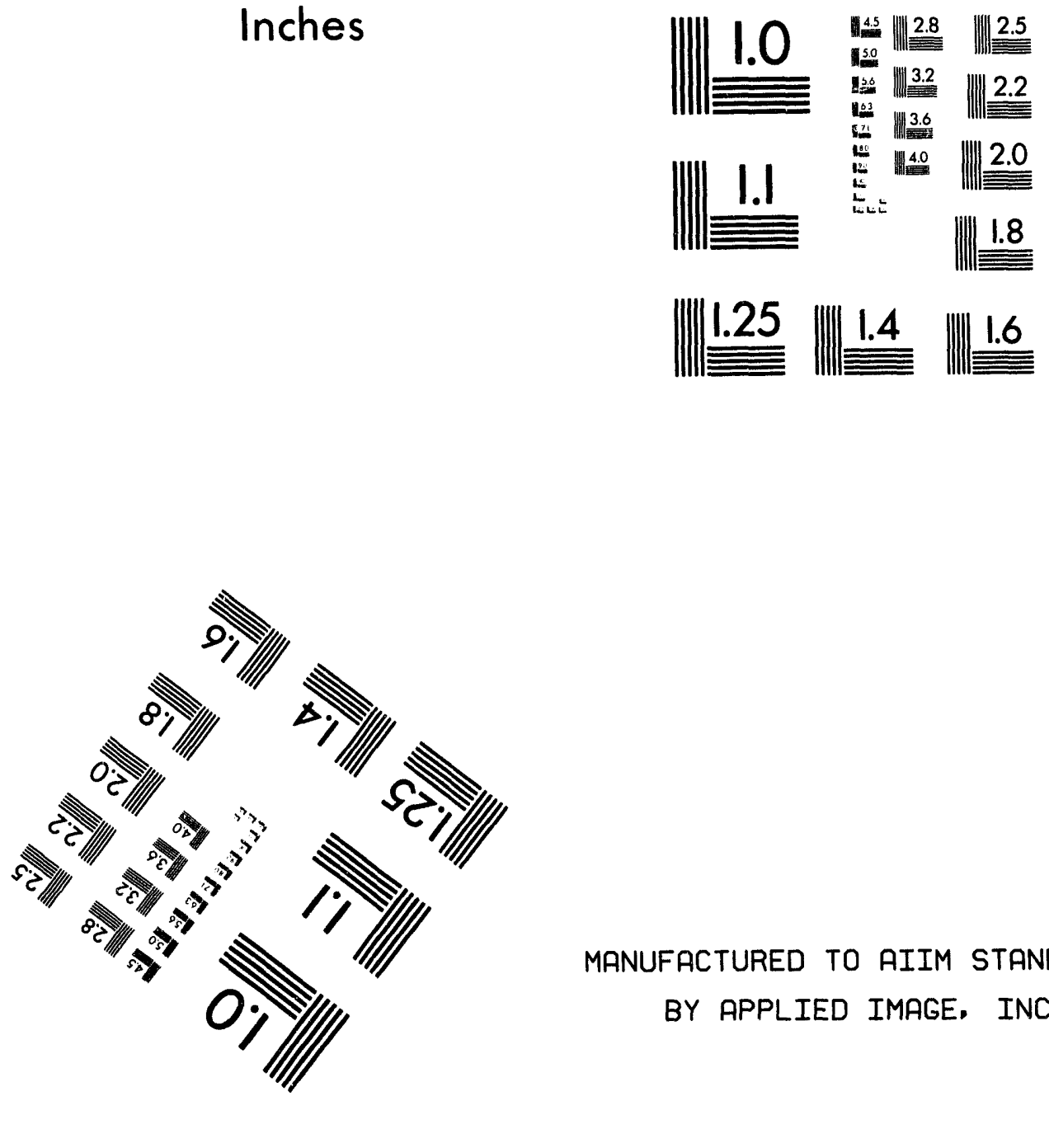

MANUFACTURED TO AIIM STANDARDS

BY APPLIED IMAGE, INC.

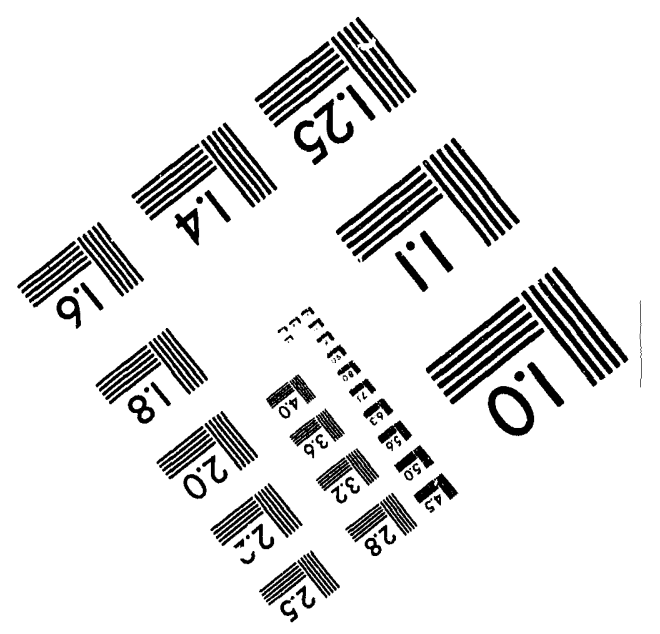



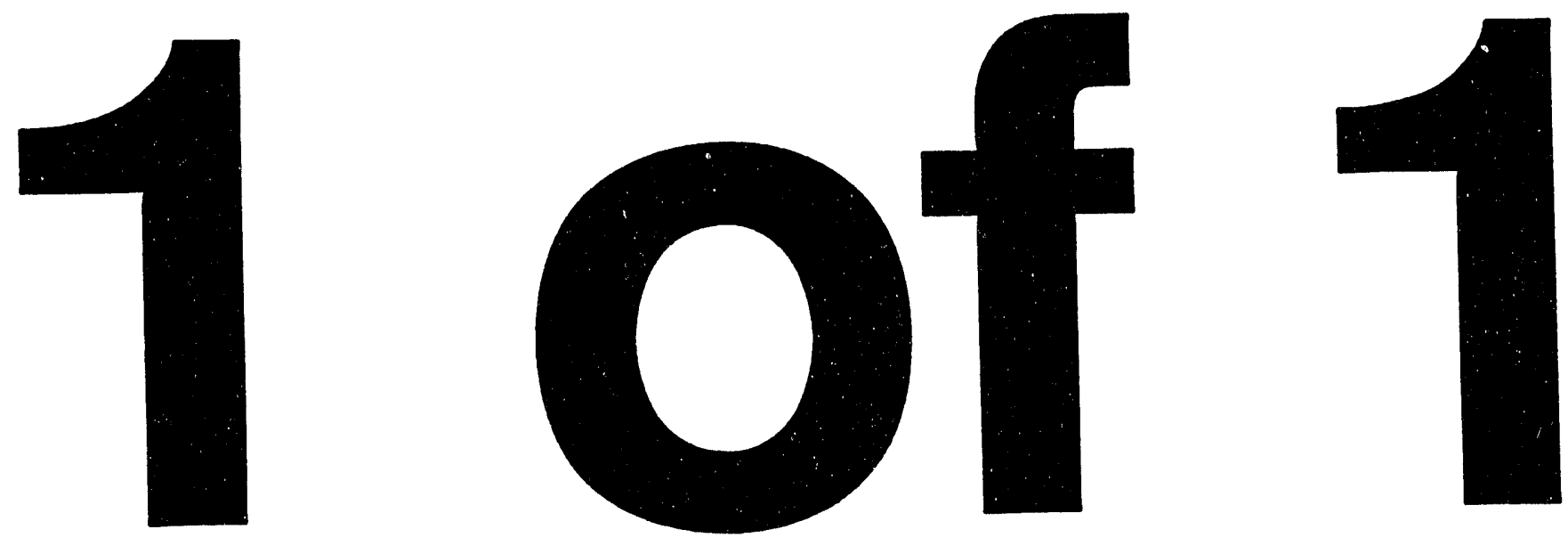


\title{
QUARTERLY PROGRESS REPORT
}

\author{
Submitted to: Department of Energy
}

\section{Effect of Pretreating of Host Oil on Coprocessing}

\author{
Contract DE-AC22-91PC91054
}

April 1 through June 30, 1994

by

\section{Chemical and Petroleum Engineering Department \\ University of Pittsburgh}

Irving Wender, Principal Investigator

John W. Tierney, Co-Principal Investigator

July 1, 1994

\section{DISCLAIMER}

This report was prepared as an account of work sponsored by an agency of the United States Government. Neither the United States Government nor any agency thereof, nor any of their employees, makes any warranty, express or implied, or assumes any legal liability or responsibility for the accuracy, completeness, or usefulness of any information, apparatus, product, or process disclosed, or represents that its use would not infringe privately owned rights. Reference herein to any specific commercial product, process, or service by trade name, trademark, manufacturer, or otherwise does not necessarily constitute or imply its endorsement, recommendation, or favoring by the United States Government or any agency thereof. The views and opinions of authors expressed herein do not necessarily state or reflect those of the United States Government or any agency thereof.

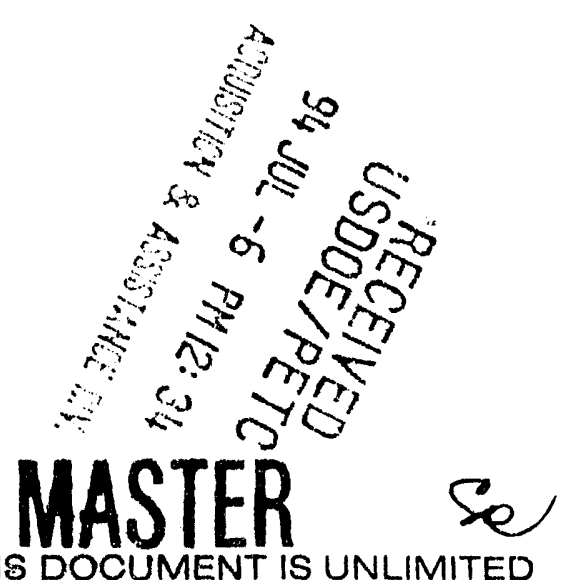




\section{INTRODUCTION}

The principal objective of this research is to gain information on the role that host petroleumderived oils $\left(1000^{\circ} \mathrm{F}+\right)$, as well as that of catalytically treated host oils, play when used as liquefaction solvents in coprocessing with coal. The host oil will be extensively characterized and then pretreated in a number of ways which involve catalytic reactions such as hydrogenation and hydrocracking. The pretreated oils will then be characterized by elemental analysis, catalytic dehydrogenation, distillation, GC-MS, and NMR. The effect of the host oil on coprocessing with coal will be compared to that obtained using catalytically modified host oils. When appropriate, model compounds will be used to study specific reactions brought about by the pretreatments.

\section{EXPERIMENTAL WORK}

During the 1st quarter of 1994 we concentrated on hydrotreating both the AMOCO and CITGO VTR with the aim of increasing their hydrogen contents through partial hydrogenation of polynuclear aromatic structures, which are present, to a limited extent, in heavy oils. Previous pretreatments with $1000 \mathrm{ppm}$ of Mo naphthenate and added sulfur at a reaction temperature of 440 ${ }^{\circ} \mathrm{C}$ and +1500 psig $\mathrm{H}_{2}$ pressure resulted in removal of sulfur and conversion to lighter distillable products but only minimal increase in hydrogen content. In an attempt to hydrogenate the heavy oils with minimal cracking we conducted several experiments using Mo naphthenate at lower 
temperatures and longer reaction times then had been previously used. Table I summarizes results of runs with the AMOCO VTR. It appears that best results were obtained by hydrotreating at $375^{\circ} \mathrm{C}$ for longer times. Under these conditions, minimal cracking of the oil resulted, as indicated by the low conversion to distillable products. However, available hydrogen content of the whole liquid product increased sharply, as indicated by the volume of gas evolved during catalytic dehydrogenation of the product (see Table I). Therefore, this preteated oil should contain more donatable hydrogen then the untreated heavy oil.

Similar results were observed for the CITGO VTR (see Table II). It appears that the temperature of the hydrotreatment is critical. Below $375^{\circ} \mathrm{C}$ cracking rates are reduced and perhaps are outpaced by hydrogenation reactions. Above $400^{\circ} \mathrm{C}$ cracking reactions dominate and probable result in destruction of hydroaromatic compounds, causing an overall drop in the available hydrogen content of the oil.

Another approach to increase hydrogen content involved treating the resids with catalysts that are only active for partially hydrogenating polynuclear aromatic compounds to form hydroaromatics. Table III shows results of two pretreatments of the CITGO VTR using $\mathrm{CO}_{2}(\mathrm{CO})_{8}$ and $\mathrm{CO} / \mathrm{H}_{2}$ gas at a ratio of 1:1. High $\mathrm{CO}$ pressure must be used to prevent dissociation of the catalysts. The results show that the cobalt catalyst was successful at adding available hydrogen even at the mild reaction temperatures used. 
Table I. Hydrotreatment Experiments of AMOCO VTR With 1000 ppm of Mo Naphthenate (300 $\mathrm{ml}$ autoclave reactor)

\begin{tabular}{||l|c|c|c|}
\hline Run \# & 54 & 72 & 73 \\
\hline Temp, ${ }^{\circ} \mathrm{C}$ & 440 & 440 & 375 \\
\hline Press, psig & 1855 & 1625 & 1690 \\
\hline Time, min & 86 & 15 & 300 \\
\hline $\begin{array}{l}\mathrm{H}_{2} \text { Consump } \\
\text { g-mol/100g }\end{array}$ & 0.70 & 0.41 & 0.31 \\
\hline $\begin{array}{l}\text { Conv, wt\% } \\
\text { (bp<800\%) }\end{array}$ & 63 & 36 & 26 \\
\hline $\begin{array}{l}\text { Catalytic } \\
\text { Dehydrogen } \\
\text { g-mol/100g }\end{array}$ & 0.29 & 0.36 & 1.11 \\
\hline
\end{tabular}

Untreated AMOCO VTR

Catalytic Dehydrogen $=0.42 \mathrm{~g}-\mathrm{mol} / 100 \mathrm{~g}$ 
Table II. Hydrotreatment Experiments of CITGO VTR (300 ml autoclave reactor)

\begin{tabular}{||l|c|c|c|c||}
\hline Run \# & 36 & 74 & 78 & 81 \\
\hline $\begin{array}{l}\text { Catalyst } \\
\text { (amount) }\end{array}$ & $\begin{array}{c}\text { Mo Naph. } \\
(500 \mathrm{ppm})\end{array}$ & $\begin{array}{c}\text { Mo Naph. } \\
(1000 \mathrm{ppm})\end{array}$ & $\begin{array}{c}\text { Mo Naph. } \\
(1000 \text { ppm })+ \\
\text { Ill\#6 coal }(10 \% \\
\text { coal })\end{array}$ & $\begin{array}{c}\text { Mo Naph } \\
(1000 \mathrm{ppm})\end{array}$ \\
\hline Temp, ${ }^{\circ} \mathrm{C}$ & 440 & 400 & 400 & 375 \\
\hline Press, psig & 2087 & 1700 & 1870 & 1690 \\
\hline Time, min & 120 & 545 & 545 & 300 \\
\hline $\begin{array}{l}\mathrm{H}_{2} \text { Consump } \\
\text { g-mol/100g }\end{array}$ & 1.1 & 0.77 & 0.77 & 0.23 \\
\hline $\begin{array}{l}\text { Conv, wt\% } \\
\text { bp<800 } \mathrm{F})\end{array}$ & 71 & 35 & 45 & 22 \\
\hline $\begin{array}{l}\text { Catalytic } \\
\text { Dehydrogen } \\
\text { g-mol/100g }\end{array}$ & 0.49 & 0.48 & 0.51 & 0.60 \\
\hline
\end{tabular}

Untreated CITGO VTR

Catalytic Dehydrogen $=0.35 \mathrm{~g}-\mathrm{mol} / 100 \mathrm{~g}$ 
Table III. Hydrotreatment Experiments of CITGO VTR in Toluene With $\mathrm{Co}_{2}(\mathrm{CO})_{8}$ and $\mathrm{H}_{2} / \mathrm{CO}=1: 1$ (300 $\mathrm{ml}$ autoclave reactor)

\begin{tabular}{||l|c|c||}
\hline Run\# & 77 & 80 \\
\hline Catalyst & $\begin{array}{c}\mathrm{Co}_{2}(\mathrm{CO})_{8} \\
(6.2 \%)\end{array}$ & $\begin{array}{c}\mathrm{Co}_{2}(\mathrm{CO})_{8} \\
(6.7 \%)\end{array}$ \\
\hline Temp, ${ }^{\circ} \mathrm{C}$ & 135 & 190 \\
\hline Press, psig & 2650 & 3000 \\
\hline Time, min & 120 & 120 \\
\hline $\begin{array}{l}\mathrm{H}_{2} \text { Consump } \\
\text { g-mol/100g }\end{array}$ & 0.25 & 0.13 \\
\hline $\begin{array}{l}\text { Conv, wt\% } \\
\text { (bp<800 } \mathrm{F} \text { ) }\end{array}$ & 0 & 0 \\
\hline $\begin{array}{l}\text { Catalytic } \\
\text { Dehydrogen } \\
\text { g-mol/100g }\end{array}$ & 0.61 & 0.57 \\
\hline
\end{tabular}

Untreated CITGO VTR

Catalytic Dehydrogen $=0.35 \mathrm{~g}-\mathrm{mol} / 100 \mathrm{~g}$ 


\section{FUTURE WORK}

The pretreated oils will next be characterized by elemental analysis to determine the extent to which hydrogen was added and sulfur and nitrogen removed. Selected pretreated oils may undergo additional characterization.

Based on preliminary results of these latest pretreatment experiments we believe that the chemical composition of the resids have been modified to significant extents. Except for a few repeat runs, this should conclude resid pretreatment experiments and we will next begin testing the pretreated oils in coprocessing.

Coprocessing experiments will be conducted in a microautoclave reactor. Initial testing will be conducted with an Illinois \#6 coal. However, coprocessing experiments will also be conducted with a second coal, a Wyodak subbituminous sample. 

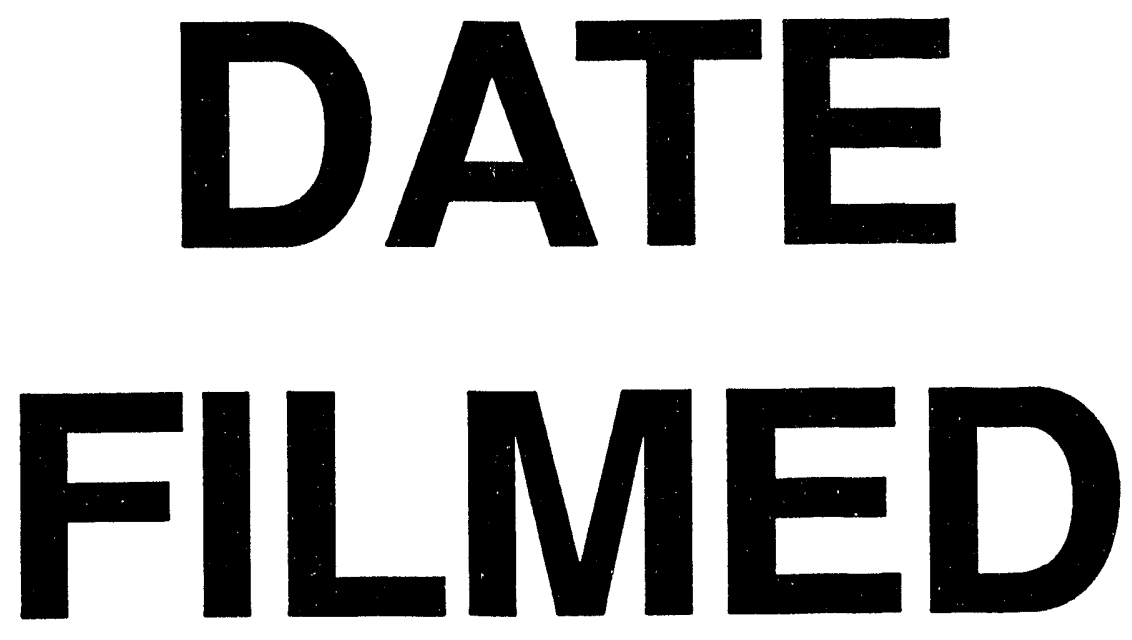

$10 / 5 / 94$
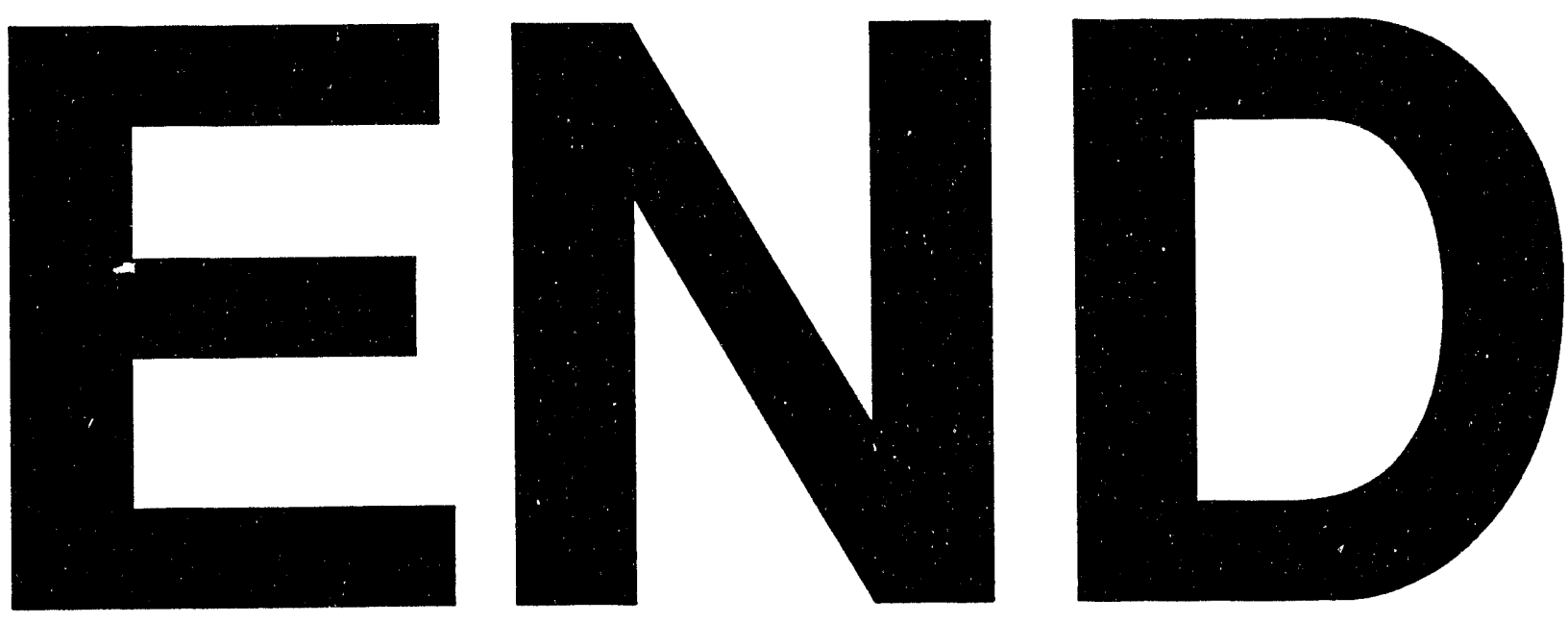
